\title{
Hvordan diagnostisere hjerteinfarkt i 2012?
}

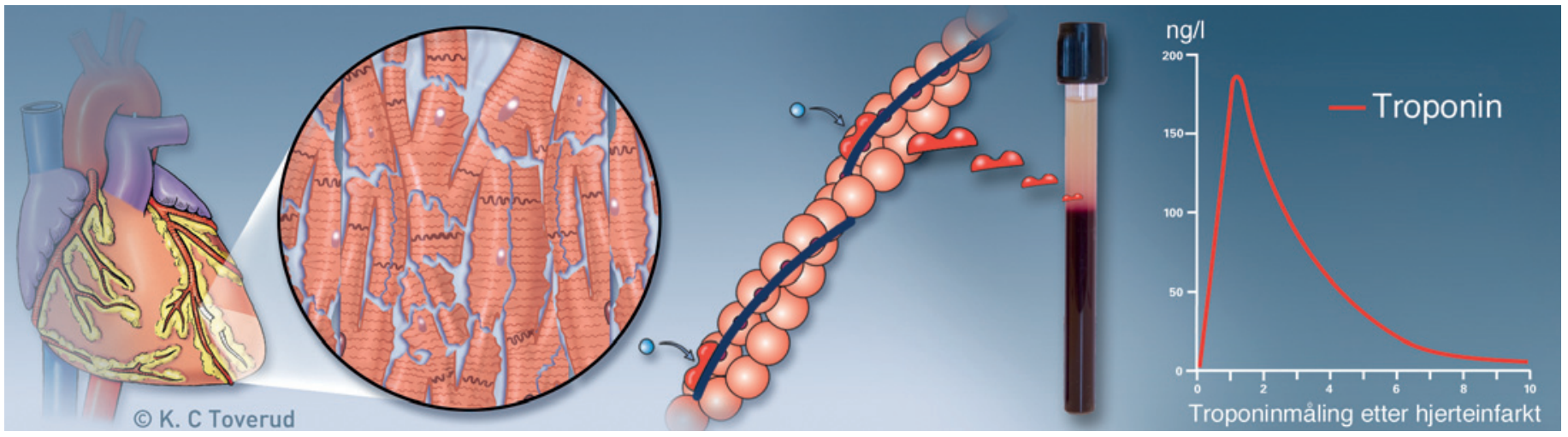

Troponinmåling etter hjerteinfarkt

I prinsippet er spørsmålet i tittelen nærmest banalt - definisjonen av infarkt er så enkel som «en myokardial nekrose i en klinisk kontekst forenlig med myokardial iskemi». Hvorfor har det da til alle tider forvoldt så store problemer å stille infarktdiagnosen klinisk? For å forstå det må vi være bevisst på hva vi har av kliniske metoder for å fange opp denne vevsnekrosen.

Den første «metoden» er den kliniske vurdering. Man må gjøre en grundig overveielse av om det foreligger symptomer - typiske eller atypiske - som er suspekte for et pågående eller gjennomgått infarkt.

Dernest har vi EKG-et. Denne teknikken, som Einthoven presenterte allerede i 1902 (1), er siden den først ble beskrevet stort sett ikke forandret. Hundre år uten endring av en medisinsk teknologi er i seg selv eksepsjonelt - Einthoven fikk med rette nobelprisen for oppdagelsen i 1924. EKG-et viser som kjent forandringer under iskemi og nekrose, særlig i ST-segmentet. Disse forandringene er praktisk talt simultane med iskemiens inntreden, og EKG-et som et øyeblikksbilde spiller derfor en sentral rolle i infarktdiagnostikken.

Enda mer sentralt er imidlertid bruken av biomarkører. Allerede i WHO-definisjonen fra 1979 ble det vektlagt like sterkt som EKGkriterier at man kunne måle CK-MB (myokardspesifikk kreatinkinase) eller andre enzymer for å understøtte infarktdiagnosen. Dette ble enda tydeligere da konsensusdokumentet Universal definition of myocardial infarction ble publisert, som avløser for WHO-definisjonen (2). Måling av de hjertespesifikke proteinene troponin I eller troponin T, med en anbefalt grenseverdi (cut-off) for infarkt liggende over 99-prosentilen og med påvist stigning og/eller fall, ble nå det aller viktigste kriterium for infarktdiagnosen, foran EKG. Dette gjelder selv om det er flere timers latens mellom nekrosens inntreden og den første måling av troponin i blodbanen. I skarp kontrast til EKG-et har man opplevd en kontinuerlig teknologisk utvikling når det gjelder måling av troponin, og den analytiske nøyaktighet er blitt dramatisk forbedret.
Den store forbedring av troponinmålingens sensitivitet har ført til at vår diagnostiske kompetanse ble stilt og stadig stilles på en særdeles hard prøve. I takt med at testenes sensitivitet øker vil man oppdage flere og flere sykdomstilstander utenom den iskemiske som årsak til troponinstigningen - altså en lavere klinisk spesifisitet for hjerteinfarkt, på tross av nærmest absolutt organspesifisitet. Dette betyr at troponinforhøyelser ikke er og heller aldri bør tolkes som spesifikke for hjerteinfarkt.

Samtidig har det økende antall troponinpositive tilstander gitt oss bedre innsikt i hjertemuskelens skademekanismer. Faktisk er mange av disse «nye» troponinstigninger forbundet med dårlig prognose, selv om de ikke kan klassifiseres som akutt koronarsykdom. Troponinstigning ses for eksempel ved nyresvikt, hjertesvikt og stabil koronarsykdom. Derfor kan vi ikke lenger operere med en dikotom diagnostisk tilnærming når det gjelder troponin - vi må ta innover oss det faktum at troponinkonsentrasjonen i blodet i realiteten utviser et kontinuum. Eller sagt på en annen måte: I fremtiden vil vi kunne måle troponin fra myokard som vi i dag måler kreatinin eller elektrolytter - alle mennesker, syke eller friske, unge eller gamle, har en verdi. Hva denne verdien uttrykker, vet vi ikke med sikkerhet, men at den gir prognostisk informasjon, er overveiende sannsynlig.

Dette kan eksemplifiseres med den nylig publiserte ASCENDHF-studien (3): $80 \%$ av pasienter innlagt i sykehus med akutt hjertesvikt, men uten akutt koronarsyndrom, hadde målbare troponiner. $51 \%$ av disse lå over 99-prosentilen, og $19 \%$ hadde stigning og fall (4). Helt nye eksperimentelle, såkalt ultrasensitive troponintester viser dessuten at det hos alle friske mennesker er målbare troponiner.

Diagnosen hjerteinfarkt er blitt ytterligere komplisert i tråd med en bredere forståelse av patofysiologien ved tilstanden. Mens det tidligere fremherskende syn var at et infarkt var utelukkende forårsaket av et rupturert plakk i en koronararterie (2), viser det seg nå at flere tilstander kan utløse et infarkt, f.eks. en ubalanse mellom oksygen- 
tilbud og -etterspørsel. Slike situasjoner ses hyppig i klinisk praksis - en episode med atrieflimmer, en dekompensert hjertesvikt, for bare å nevne noen få. Denne forståelse har ført oss så langt at vi nå for første gang står overfor en kategorisering av hjerteinfarkt: type 1 for koronartrombose, type 2 for oksygenubalanse osv. (2).

Hvor står vi i dagens situasjon? Ikke overraskende hersker det forvirring. Behovet for kardiologisk tilsyn stiger i takt med at flere og flere pasienter har positive troponinverdier. Noen har myntet det sarkastiske begrep «troponitis» om disse pasientenes tilstand. Usikkerheten knytter seg videre til spørsmålet om man overhodet kan stole på 99-prosentilen som infarktgrenseverdi, selv om flere og flere data tilsier at nettopp den økte troponinsensitiviteten identifiserer flere høyrisikopasienter og at dette fører til mer målrettet behandling og høyere overlevelse (5). Dessuten er det usikkerhet rundt kravet om «stigning og fall» av troponinnivå (2), som er helt avhengig av tidsvinduet når blodprøven blir tatt i forhold til infarktet. Man står igjen med det uomtvistelige krav om at hver enkelt pasient må bedømmes i sin kliniske kontekst, slik at diagnosesettingen «hjerteinfarkt» er basert på mer enn bare EKG og troponinmålinger. Til tross for dagens sofistikerte diagnostiske teknologi bør infarktdiagnosen forbeholdes de pasienter der også de tilgjengelige kliniske opplysninger sannsynliggjør at en slik hendelse har funnet sted.

\section{Dan Atar}

dan.atar@oslo-universitetssykehus.no Oslo universitetssykehus, Ullevål

Universitetet i Oslo

Dan Atar (f. 1959) er spesialist i indremedisin og kardiologi. Han er avdelingsoverlege ved kardiologisk avdeling, Oslo universitetssykehus, Ullevål, og professor i kardiologi ved Universitetet i Oslo.

Ingen oppgitte interessekonflikter.

\section{Litteratur}

1. Einthoven W. Galvanometrische registratie van het menschelijk electrocardiogram. I: Rosenstein SS. Herrineringsbundel. Leiden: Eduard Ljdo, 1902: 107.

2. Thygesen K, Alpert JS, White HD et al. Universal definition of myocardial infarction. Circulation 2007; 116: 2634-53

3. O'Connor CM, Starling RC, Hernandez AF et al. Effect of nesiritide in patients with acute decompensated heart failure (ASCEND-HF). N Engl J Med 2011; 365: 32- 43.

4. Felker GM, Hasselblad V. Tang W et al. Troponin I in acute decompensated heart failure: insights from the ASCEND-HF study. J Am Coll Cardiol 2012; 59: akseptert for publisering.

5. Mills NL, Churchhouse A, Lee KK et al. Implementation of a sensitive troponin I assay and risk of recurrent myocardial infarction and death in patients with suspected acute coronary syndrome. JAMA 2011; 305: 1210-6. 